\title{
A novel recombinant baculovirus overexpressing a Bacillus thuringiensis Cry1 Ab toxin enhances insecticidal activity
}

\author{
Wael El-Menofy ${ }^{1}$, Gamal Osman ${ }^{1,2^{*}}$, Abdulrahman Assaeedi ${ }^{2}$ and Mohamed Salama ${ }^{3}$
}

\begin{abstract}
Baculoviruses have been genetically modified to express foreign genes under powerful promoters in order to accelerate their speed of killing. In this study a truncated form of cry $1 \mathrm{Ab}$ gene derived from Bacillus thuringinsis (Bt) subsp. aegypti isolate Bt7 was engineered into the genome of the baculovirus Autographa californica multiple nuclearpolyhedrosis wild type virus, in place of the polyhedrin gene by using homologous recombination in Spodoptera frugiperda (Sf) cells between a transfer vector carrying the Bt gene and the wild type virus linearized DNA. Recombinant wild type virus containing the cry $1 \mathrm{Ab}$ gene was detected as blue occlusion-negative plaques in monolayers of $\mathrm{Sf}$ cells grown in the presence of X-Gal. In Sf cells infected with plaque-purified recombinant virus, the cry $1 \mathrm{Ab}$ gene was expressed to yield a protein of approximately $82-\mathrm{kDa}$, as determined by immunoblot analysis. The toxicity of the recombinant virus expressing the insecticidal crystal protein (ICP) was compared to that of the wild-type virus. Infected-cell extract was toxic to cotton leaf worm Spodoptera littoralis second instar larvae and the estimated $L_{5}$ was $1.7 \mu \mathrm{g} / \mathrm{ml}$ for the recombinant virus compared with that of wild-type virus which was $10 \mu \mathrm{g} / \mathrm{ml}$.
\end{abstract}

Keywords: Bacillus thuringiensis, Toxin, Baculovirus, Cry $1 \mathrm{Ab}, \mathrm{LC}_{50}$

\section{Introduction}

The development of synthetic pesticides since 1940 coupled with the improvement in chemical applications technology dramatically increased the potential for agricultural pest control [1]. It did not take long before people began to see the shortcomings of this new technology. Pests that had been naturally controlled by predators and parasites began to cause significant damage and became resistant to chemical pesticides [2]. Moreover, chemical pesticides have become expensive and imposed greater hazard to the environment and all living organisms [3]. An alternative strategy for effective control of pests is the use of biological insecticides either by itself or within an integrated pest management program (IPM) $[4,5]$. The benefit of biological control by viruses, especially baculoviruses has become apparent in recent years. Baculoviruses are major insect pathogens and are characterized by the

\footnotetext{
* Correspondence: geosman@uqu.edu.sa

${ }^{1}$ Agricultural Genetic Engineering Research Institute (AGERI) - ARC, 9 Gamaa

St, Giza, Egypt

${ }^{2}$ Biology Department, Faculty of Applied Sciences, Umm Al Qura University, Makka 21955, PO Box 715, Kingdom of Saudi Arabia

Full list of author information is available at the end of the article
}

presence of a large circular double stranded DNA genome and enveloped rod shaped virions. Baculoviruses and their use as biological insecticides have been studied for several years [6]. Since baculoviruses are host-specific and do not infect vertebrates or plant species, and considered to be the best among viruses for insect pest control [7]. More than 600 insect species serve as hosts for baculoviruses, which belong to family baculoviridae [8]. They are insect pathogens and cause fatal disease in insects mainly in members of Lepidopteran order [9-11]. However, wild type baculoviruses have several limitations in their use as biological control agents [12]. The major problems are the slow speed of action, low virulence to older instar larvae and sensitivity to UV-light [13]. Development of genetically engineered viruses has resulted in an enhancement of the speed with which baculoviruses kill target pests by introducing additional pesticidal genes into the genome of Autographa californica nucleopolyhedrovirus wild type virus. These recombinant baculoviruses were evaluated under laboratory conditions for their improved pesticidal properties $[7,14]$. Because the C-terminal half of $135-\mathrm{kDa}$ Cry1 is not toxic, it could be eliminated and use 
only the $\mathrm{N}$-terminal half, in the same time the truncated proteins do not form inclusions. These insecticidal transgenes included insect hormone genes which disturb the physiological hormonal balance of the insect $[15,16]$ and Bt gene(s). [1,17,18]. Moreover, the production of recombinant baculoviruses expressing specific neurotoxin proteins such as mite toxin and the scorpion toxin [19-21] enhanced the biological activity of baculoviruses. This study aims to introduce a truncated cry1Ab gene from Bacillus thuringiensis into a baculovirus in order to enhance its insecticidal activity.

\section{Materials and methods}

\section{Bacterial strains}

Bacillus thuringiensis local Egyptian isolate Bt7 was provided by Prof. G. Osman Agricultural Genetic Engineering Research Institute (AGERI). Escherchia coli strain XL-1 blue (Stratagene Inc. 1 north state st suite 900, Chicago, 606062, USA) was used as the host for plasmid DNA preparation and propagation.

\section{Virus}

Autographa californica nucleopolyhedrovirus wild type virus, strain E2 [22] was used as a wild type (wt) virus (supplied by Invitrogen, 3175 Staley Road, Grand Island, NY 14072, USA).

\section{Insects cell culture}

Spodoptera frugiperda cell line IPLB SF21-AE (Sf 21) was kindly provided by Dr. Hussen, A. Virology Dept. Faculty of Veterinary, Cairo University, Giza, Egypt. Sf21 cells were maintained at $27^{\circ} \mathrm{C}$ and grown in a TNM-FH medium that was supplemented with $10 \%(\mathrm{w} / \mathrm{v})$ fetal bovine serum and antibiotics, and subcultured every 3 to 4 days.

\section{Insects}

Cotton leaf worm (Spodoptera littoralis - Boisd - Noctuidae - Lepidoptera), was provided by Insectary of (AGERI), Giza, Egypt. The Egyptian cotton leaf worm Spodoptera littoralis (Biosd) were reared in insectary of AGERI under highly controlled conditions the larvae were fed on semisynthetic diet described by Shorey and Hale [23], the insect culture were maintained on $25+$ or $-2^{\circ} \mathrm{C}, 65-70 \% \mathrm{RH}$ and natural photoperiod.

\section{Construction of a transfer vector containing the truncated cry1 Ab gene}

Cry1Ab toxin was chosen because of its high insecticidal activity against Spodoptera sp. The truncated form of the cry1Ab gene, encoding the $82 \mathrm{kDa}$ toxin protein was cloned from Bt7 strain followed by determination of its DNA sequences. The truncated cry1Ab gene was amplified using one pair of specific primers (WG1 and
WG2) based on the nucleotide sequence of the published cry $1 \mathrm{Ab}$ gene.The cry1Ab fragment $2.2 \mathrm{~kb}$ was amplified by using a pair of specific primers i.e.WG1 forward (5' ATGGATAACAATCCGAACATC3') and WG2 reverse (5' TAGCGTAACGTAATT CTCTTT 3'). The primer was designed according to cry1Ab gene in gene bank accession number: gbKF93868.2.1. The amplified DNA fragment was cloned into pGEM-T easy vector (Promega, 2800 Woods Hollow Road, Madison, WI 53711 USA ). The new construct was named wpGM-Bt7. The wpGM-Bt7 was subcloned into pBlueBacIII transfer vector (Invitrogen) by restriction digestion using $\mathrm{NcoI}$ and Pst endonucleases. The newly constructed plasmid named wpBac-Bt7.

\section{Co-transfection of Spodoptera frugiperda cells and isolation of recombinant virus}

Recombinant wild type baculovirus, containing the cry1 Ab gene under transcriptional control of the polyhedrin promoter was introduced by in vitro homologues recombination as described in the Invitrogen instruction manual. Linear viral DNA (500 ng) was co-transfected with (1-2 ug) wpBac-Bt7 containing the cry1Ab into $S$. frugiperda Sf21 cells using liposome-mediated transfection method according to Webb and Summers [24]. After $48 \mathrm{~h}$ the medium from transfected cells was collected. For plaque assay screening, three viral serial dilutions $\left(10^{-1}, 10^{-2}\right.$ and $\left.10^{-3}\right)$ were mixed with $1 \times 10^{6} \mathrm{~S}$. frugiperda cells Sf 21 and seeded in complete TC-100 medium in $60 \mathrm{~mm}$ dishes (Falcon Invitrogen) for $1 \mathrm{~h}$. After incubation, the media were completely removed from all plates and the infected cells were overlaid with the supplemented TC-100 medium containing $0.5 \%$ baculovirus agarose and $150 \mu \mathrm{g} \mathrm{ml}^{-1} \mathrm{X}$-gal (5-bromo-4-chloro-3-indolyl-ßD-galactopyranoside) as a chromogenic substrate. The plates were incubated at $27^{\circ} \mathrm{C}$ for five days and screened for the presence or absence of polyhedra by light microscopy. Plaque forming units (pfu) were detected as blue spots after five to six days post-infection (p.i.) and polyhedrin negative blue plaque were visualized using an inverted light microscope. The presence of Bt gene cry1Ab in the recombinant virus AcW-Bt7 were confirmed by PCR using WG1 and WG2 specific primers.

\section{Analysis of protein expression by SDS-PAGE and Immunoblotting}

Insect cells were infected with AcW-Bt7 at a multiplicity of infection (moi) of (10 moi/cell) recombinant virus. The expression of the crystalline protein of cr1Ab in the insect cells was detected by SDS-PAGE and immunoblotting assay. Sf cells infected with the recombinant virus were lysed in electrophoresis sample buffer $\left(0.06 \mathrm{~mol}^{-1}\right.$ Tris$\mathrm{HCl} \mathrm{pH} \mathrm{6.8,} \mathrm{2 \%} \mathrm{SDS,} \mathrm{10 \%} \mathrm{glycerol,} \mathrm{5 \%} \mathrm{b-mercaptoethanol}$ and bromophenol blue). Samples were denatured for five min in boiling water and separated in $10 \%$ polyacrylamide 
gel [25]. Gels were stained with $0.1 \%$ Coomassie blue $\mathrm{R}-250$ in $7 \%(\mathrm{v} / \mathrm{v})$ acetic acid and 50\% methanol. The gels were destained in $7 \%(\mathrm{v} / \mathrm{v})$ acetic acid with $50 \%$ methanol. For immunodetection, proteins were transferred using a semi-dry blotter (Bio-Rad) on to a PVDF membrane (Millipore) and probed with an antibody directed against the Cry1A protein. The immune-detection was performed using the ECL kit from Amersham Bioscience, church farm business park, corston bath Ba2 9Ap, UK.

\section{Bioassay of the recombinant virus}

The bioassay of infected Sf 21 cells with recombinant virus against second instar of cotton leaf worm compared to the wild type virus. Sf 21 cells were infected at an moiof 10 and collected at 72-h post infection (p.i.). For each virus, the cells were washed twice with PBS freeze-thawed several times to disrupt the cell membrane then the samples were diluted over a concentration range of 1.5$300 \mu \mathrm{g} \mathrm{ml} \mathrm{m}^{-1}$ of polyhedra then assayed against second instar larvae of cotton leaf worm (CLW) as described by Ibara and Federici [26]. For each viral concentration Twenty second instar larvae were added in each cup. Bioassays were repeated three times. Mortality was scored daily until death or pupation. The $\mathrm{LC}_{50}$ was determined by probit analysis plot [27]. Control treatments consisted of uninfected larvae and infected larvae with wild type virus.

\section{Results}

\section{Cloning of Bacillus thuringiensis cry1Ab Gene}

PCR was carried out to amplify a $2.2 \mathrm{~kb}$ fragment by using whole Bt7 genomic DNA as a template. The PCRamplified DNA fragment was purified and cloned in TA cloning vector (pGEM-T-Easy vector, Promega). Screening for the positive clones (white colonies) was done using of both single and double restriction enzyme digestion. The new construct was named wpGM-Bt7. DNA sequencing of cry $1 \mathrm{Ab}$ gene was carried out using the automated sequencer ABI PRISM 310. The sequence analysis of cry1 $\mathrm{Ab}$ indicated that the amplified fragment is a typical Bt gene with low $\mathrm{G}+\mathrm{C}$ content (37.63\%) and high $\mathrm{A}+\mathrm{T}$ content (62.37\%). Moreover, the nucleotide sequence alignment of the cry1Ab gene revealed that the cry $1 \mathrm{Ab}$ of Bt7 had an identity of $98 \%$ with the Genbank cry $1 \mathrm{Ab}$ sequence while it was $100 \%$ identity with the Genbank at amino acid level. The sequence of crylAb gene of the isolate was submitted to GenBank with the accession \#KC581790.

\section{Sub-cloning of cry1 Ab into pBlueBaclll baculovirus transfer vector}

cry1Ab was subcloned into non-fused pBlueBacIII baculovirus transfer vector under the control of the polyhedrin gene promoter. Screening of the baculovirus hybrid plasmids using double digestion with NcoI and PstI endonucleases showed an 2.2 kb DNA fragment corresponding to the expected size of the cry $1 \mathrm{Ab}$ gene. The resulting hybrid plasmid was named wpBac-Bt7.

\section{Generation and purification of genetically modified wild type virus containing cry $1 \mathrm{Ab}$ gene}

Wild type baculovirus was chosen to be the parental virus for generation of recombinant virus by using the homologous recombination method. Sf cells were cotransfected with baculovirus hybrid plasmid wpBac-Bt7 and the linearized wild type virus DNA to facilitate the replacement of the cry1Ab gene (located in the hybrid plasmid) in place of the polyhedrin gene (located in the wild type baculovirus genome) via homologues recombination in the presence of Cellfectin cationic liposome reagent (Figure 1). Recombinant virus was distinguished from the wild type virus by using the plaque assay method [28]. Four blue plaques were selected. They indicated the occurrence of homologues recombination within the insect cell and resulted in a recombinant virus which carried the Bt cry1 Ab gene with blue plaque phenotype and named AcW-Bt7. This result was further confirmed by detection of cry1Ab gene through PCR (Figure 2). SDS-PAGE of the total protein extract of infected cells (Figure 3) and also Western blot analysis of the protein profile by using a polyclonal antibody specific for the Cry1Ab protein, confirmed the presence of the $82 \mathrm{kDa}$ protein band, which reacted successfully with the Cry1A specific antibody (Figure 4).

Insect toxicity and bioassay of the recombinant baculovirus The biological activity of the AcwBt7 recombinant virus expressing Bt Cry1Ab toxin protein was evaluated against cotton leaf worm Spodoptera littoralis $2^{\text {nd }}$ instar larvae. The $\mathrm{LC}_{50}$ value for $\mathrm{Acw}-\mathrm{Bt} 7$ and the wild type virus were determined by feeding of $2^{\text {nd }}$ instar larvae of cotton leaf worm on a semi-artificial diet with different concentrations of the final whole culture (FWC) ranging from 1.5-300 $\mu \mathrm{g} \mathrm{ml}^{-1}$ for both the recombinant virus Acw-Bt7 and virions of the wild type virus. The results of the bioassay revealed that the $\mathrm{LC}_{50}$ value for the recombinant virus was $1.7 \mu \mathrm{g} \mathrm{ml}^{-1}$, compared to the $\mathrm{LC}_{50}$ value for the wild type virus which was $10 \mu \mathrm{g} \mathrm{ml}^{-1}$. Regression analysis of the cotton leaf worm larval response to Acw-Bt7 (recombinant virus) and wild type virus are illustrated in (Figure 5). The $\mathrm{LC}_{50}$ was determined by probit analysis plot [27]. Control treatments consisted of uninfected larvae and infected larvae with wild type virus.

These result of the bioassay revealed that the recombinant virus is five-fold more effective than the wild type. 

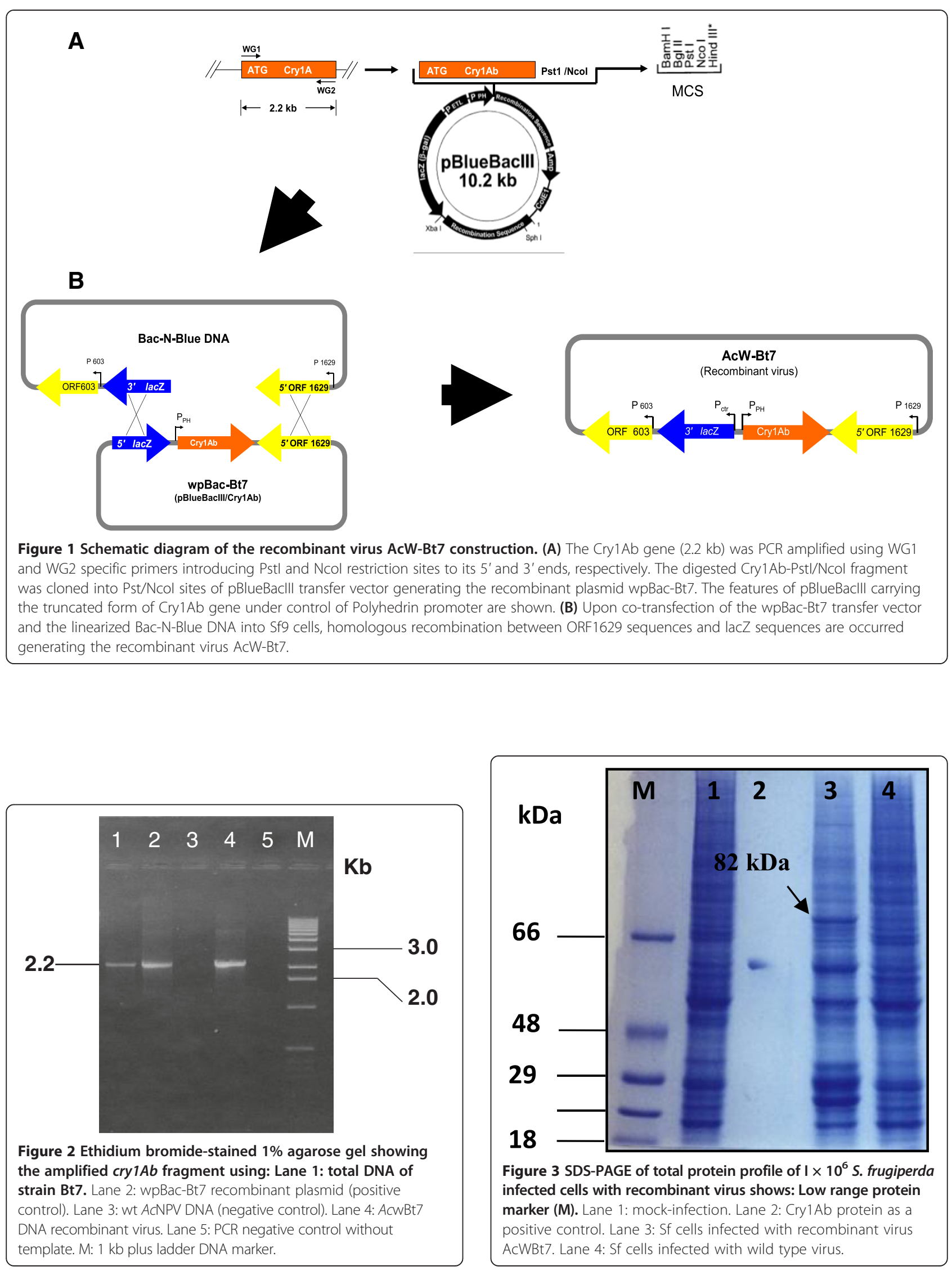


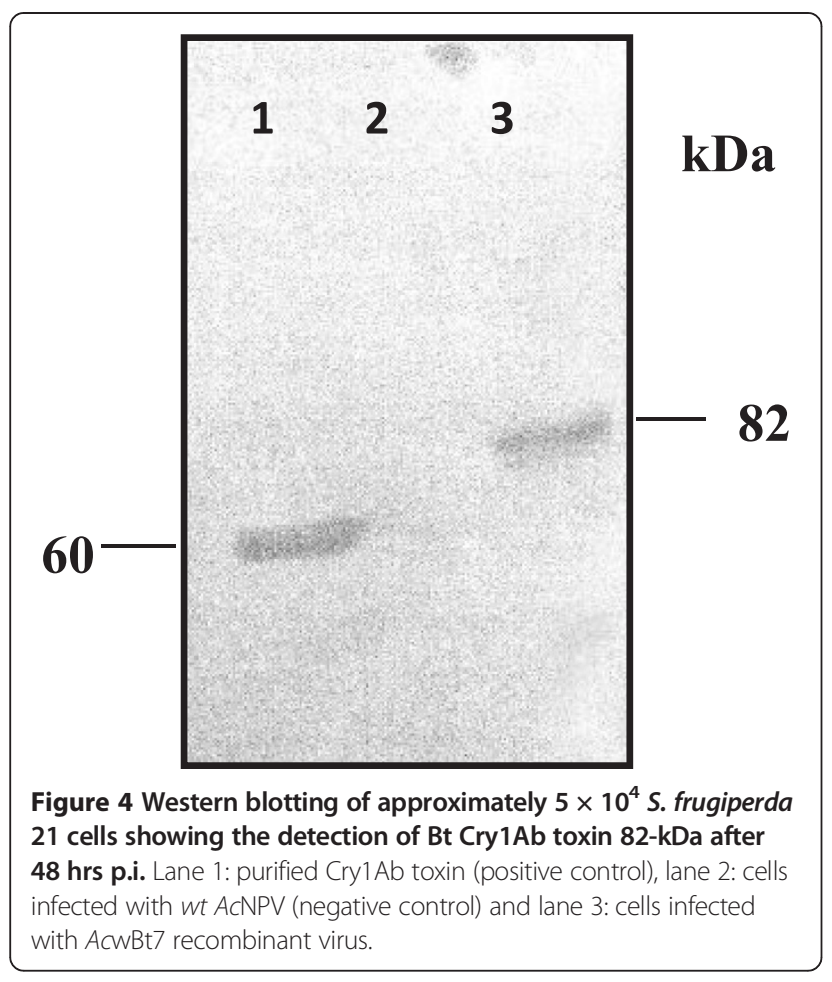

\section{Discussion}

Because the C-terminal half of $135-\mathrm{kDa}$ Cry1 is not toxic, it could be eliminated and use only the N-terminal half, in the same time the truncated proteins do not form inclusions. A recombinant virus containing the truncated crylAb gene from Bacillus thuringiensis Bt7 was constructed successfully. The insecticidal crystal protein

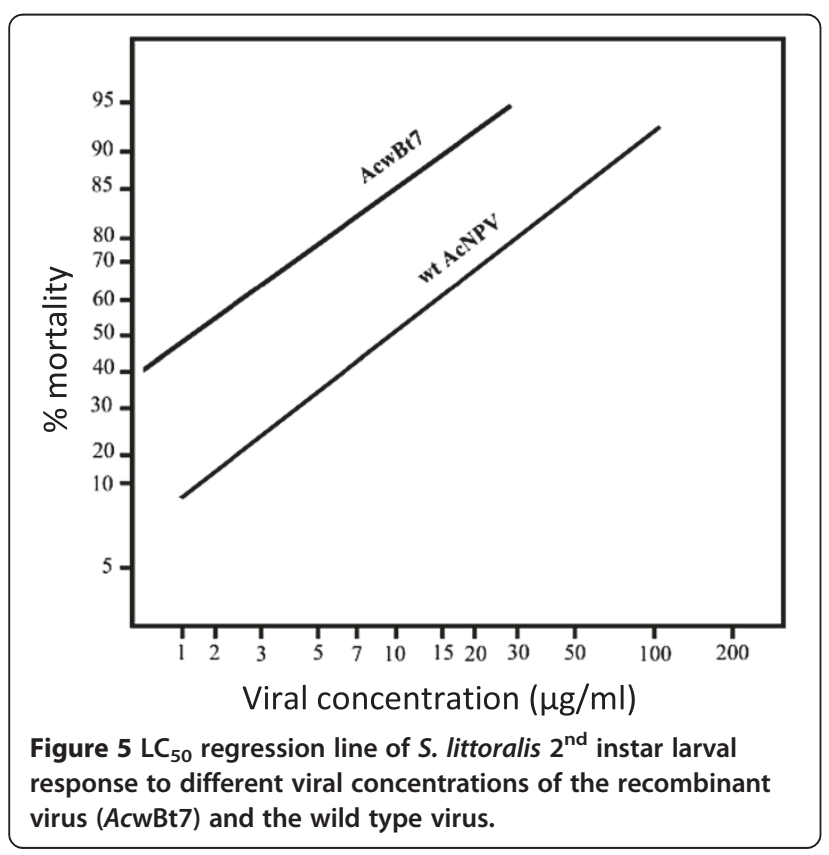

(ICP) Cry1 Ab of $82 \mathrm{KDa}$ was produced in the infected Sf cells. These results proved that wild type baculovirus can be used to express and study the properties of the insecticidal Bacillus thuringiensis protein yielding information relevant to an understanding of the molecular biology of this protein as well as to improve the baculovirus insecticidal activity. These results agree with the findings of $[29,30]$, who introduced a truncated (orf) gene coding for the $\mathrm{N}$-terminal 645 amino acids of the protoxin in a similar way into a wild type virus to avoid crystal formation. This protein produced in considerable amounts was biologically active, but as expected, did not precipitate into crystals confirming that the C-terminal part of the Cry1 Ab ICP is required for crystal formation [31,32]. Chang et al. [30] noted also that the complete cry1 Ab open reading frame (orf) crystal protein expressed by AcNPV/JM3 recombinant virus from the polyhedrin promoter in $S f$ cells was highly toxic to $P$. brassicae larvae. These results indicated that the wild type baculovirus-expressed ICP is authentic and could in principle enhance the insecticidal action of a recombinant baculovirus. The results of the bioassay revealed that the $\mathrm{LC}_{50}$ value for the recombinant virus was $1.7 \mu \mathrm{g} \mathrm{ml}^{-1}$, compared to the $\mathrm{LC}_{50}$ value for the wild type which was $10 \mu \mathrm{g} \mathrm{ml}^{-1}$. These results of the bioassay revealed that the recombinant virus is 5 -fold more effective than the wild type virus, and this results will encourage us to test this recombint virus on other lepidoperan pests. This is in agreement with the results of [33-35], who noted that the level of expression of the Cry1Ab and Cry1Ac proteins in insect cells infected with the occluded viruses (p10- based promoter) $A c \mathrm{OBtm}$ and $A c \mathrm{OBt} 73 \mathrm{had}$ at least 1/5 of the expression of the same proteins in insects infected with the non-occluded viruses (polyhedrin-based promoter), AcBtm and AcBt73. This lower expression could be due to the simultaneous expression of the polyhedrin gene, since they might compete for the same resources or transcription factors inside the cell. The toxic action of $\mathrm{Bt}$ in vivo is known to be dependent on the binding of activated toxin to the external surface of midgut microvilli, where the toxins appear to bind to specific proteins receptors [36,37] and then intercalate forming transmembrane cation pores [38] that lead to cell death. However, it has been shown that the Cry1A and CryIIIA toxins can insert into planar lipid bilayers that have no protein receptors $[30,39]$. Moreover, evidence from patch clamp studies of the action of the CrylC toxin on $S f$ cells indicated that this Bt toxin may act inside the cell and is capable of inserting into the cell membrane from the cytoplasmic side $[40,41]$. These results are consistent with that of $[8,42])$, who reported that the normal targets of the $\delta$ endotoxin are the gut epithelial cells. However, several other types of cell have also been shown to have receptors for the toxins $[11,43]$. Characterization of factors 
determining the host-range of the baculoviruses may lead to greater potential for manipulation of the host-range. Considering that the use of baculoviruses may increase substantially in the next 10 years [44]. With growing awareness of environmental issues associated with expanding the demand for effective bioagents although Baculoviruses are essentially nonpathogenic to mammals as well Bt these may be need further study in terms of Biosafety of recombinant baculovirus as a result of viral genome alteration.

\section{Competing interest}

The authors declare that they have no competing interest.

\section{Authors' contributions}

Developing original approach (GO), improving and confirming the technique (MS, GO), performing experiment (GO, WE, MS), analyzing data (WE, GO, AA), writing the manuscript (AA, GO), molecular genetic studies (GO, WE), participated in the sequence alignment and drafted the manuscript (GO, AA). All authors read and approved the final manuscript.

\section{Acknowledgements}

The Authors are grateful to Professor Subertnam Muthukrishnan, professor of Biochemistry, Biochemistry department, Kansas state university, USA. for going through the manuscript and making valuable suggestions.

\section{Author details}

${ }^{1}$ Agricultural Genetic Engineering Research Institute (AGERI) - ARC, 9 Gamaa St, Giza, Egypt. ${ }^{2}$ Biology Department, Faculty of Applied Sciences, Umm Al Qura University, Makka 21955, PO Box 715, Kingdom of Saudi Arabia. ${ }^{3}$ Faculty of Science, Ain Shams University, Cairo, Egypt.

Received: 29 January 2014 Accepted: 29 March 2014

Published: 15 April 2014

\section{References}

1. Osman G: Detection, Cloning and Bioinformatics Analysis of vip1/vip2 Genes from Local Bacillus thuringiensis. Afr J Biotechnol 2012, 11(54):11678-11685

2. EL-Ghareeb DK, Osman GH, AF E b: Isolation, cloning, and overexpression of vip3Aa gene isolated from a local Bacillus thuringiensis. Biocontrol Sci Techn 2012, 22(No. 1):11-21.

3. Inceoglu AB, Kamita SG, Hammock BD: Genetically modified baculoviruses: A historical overview and future outlook. Adv Virus Res 2006, 68:323-360.

4. Harrison RL, Bonning BC: Use of proteases to improve the insecticidal activity of baculoviruses. Biol Control 2001, 20:199-209.

5. Assaeedi A, Osman G, Abulreesh $\mathrm{H}$ : The occurrence and insecticidal activity of Bacillus thuringiensis in the arid environments. AJCS 2011, 5:1185-1190.

6. Li L, Kim YS, Hwang DS, Seo JH, Jung HJ, Juan D, Cha HJ: High and Compact Formation of Baculoviral Polyhedrin-Induced Inclusion Body by Co-Expression of Baculoviral FP25 in Escherichia coli. Biotechnol Bioeng 2007, 96(6):1183-1190

7. Choi JY, Wang Y, Kim YS, Kang JN, Roh JY, Woo SD, Jin BR, Je YH: Insecticidal activities of recombinant Autographa californica nucleopolyhedrovirus containing a scorpion neurotoxin gene using promoters from Cotesia plutellae bracovirus. J Asia Pac Entomol 2008, 11:155-159.

8. Hee JS, Choi JY, Li MS, Wang Y, Roh JY, Woo S-D, Jin BR, Je YH: A novel recombinant baculovirus expressing insect neurotoxin and producing occlusion bodies that contain Bacillus thuringiensis Cry toxin. J Asia PaC Entomol 2009, 12:217-220.

9. Martignoni ME, Iwai PJ: A Catalog of Viral Diseases of Insects, Mites and Ticks. USDA Forest Service PNW-195. USGPO: Washington, DC: 1986

10. Murphy FA, Fauquet CM, Bishop DHL, Ghabrial SA, Javis AW: Virus Taxonomy. In $6^{\text {th }}$ Rep. Int. Comm. Taxon. Viruses. New York: Springer-Verlag 1995:110-113.
11. Jeong Hyun S, Joo Sang Y, Hyung Joon C: Baculoviral Polyhedrin-Bacillus thuringiensis Toxin Fusion Protein: A Protein-Based Bio-Insecticide Expressed in Escherichia coli. Biotechnol Bioeng 2005, 92(NO. 2):166-172.

12. Choo YM, Lee KS, Yoon HJ, Qiu Y, Wan H, Sohn MR, Sohn HD, Jin BR: Antifibrinolytic role of a bee venom serine protease inhibitor that acts as a plasmin inhibitor. PLoS One 2012, 7:e32269.

13. Choo YM, Lee KS, Yoon HJ, Kim BY, Sohn MR, Roh JY, Je YH, Kim NJ, Kim I, Woo SD, Sohn HD, Jin BR: Dual function of a bee venom serine protease: prophenoloxidase-activating factor in arthropods and fibrin(ogen)olytic enzyme in mammals. PLoS One 2010, 5:e10393.

14. Bonning BC, Hammock BD: Development of recombinant Baculovirus for insect control. Annu Rev Entomol 1996, 41:191-210.

15. Maeda S, Mkohara Y, Kondo A: Characteristically distinct isolates of the nuclear polyhedrosis virus from Spodoptera Litura. J Gen Virol 1990, 71:2631-2639.

16. Choi JY, Li MS, Shim HJ, Roh JY, Woo SD, Jin BR, Boo KS, Je YH: Isolation and characterization of strain of Bacillus thuringiensis subsp. kenyae containing two novel cry1-type toxin genes. J Microbiol Biotechnol 2007, 17:1498-1503.

17. Martens JWM, Visser B, Vlak JM, Bosch D: Precise mapping and characterization of the entomocidal domain of the Bacillus thuringiensis Cry1A(b) protoxin. Mol Gen Genetics 1995, 247:442-487.

18. Ventura $S$, Villaverde A: Protein quality in bacterial inclusion bodies. Trends Biotechnol 2006, 24:179-185.

19. Tomalski MD, Miller LK: Insect paralysis by baculovirus mediated expression of a mite neurotoxin gene. Nature 1991, 352:82-85.

20. Stewart LM, Hirst M, Ferber ML, Meryweather AT, Cayley PJ, Possee RD: Construction of an improved baculovirus insecticide containing an insect-specific toxin gene. Nature 1991, 352:85-88.

21. Maeda S, Volrath S, Hanzlik TN, Harper SA, Majima K, Maddox DW, Hammock $B D$, Fowler $E$ : Insecticidal effects of an insect-specific neurotoxin expressed by a recombinant baculovirus. Virology 1991, 184:777-780.

22. Smith GE, Summers MD: Analysis of baculovirus genome with restriction endonucleases. Virology 1978, 98:517-527.

23. Shorey $\mathrm{H}$, Hale R: Mass rearing of larvae of nine Noctuid species on a simple artificial diet J. Econ Entomol 1965, 58:522-528.

24. Webb NR, Summers MD: Expression of proteins using recombinant baculoviruses. Technique 1990, 2:173-188.

25. Laemmli UK: Cleavage of structural protein during the assembly of the head of bacteriophage T4. Nature 1970, 227:680-685.

26. Ibara JE, Federici BA: An alternative bioassay employing neonate larvae for determining the toxicity of suspended particles to mosquitoes. J Amer Mosqu Cont Soci 1987, 3:187-192.

27. Finny D: Probit analysis. Cambridge: Cambridge University Press; 1962.

28. Summers MD, Smith GE: A manual of methods for baculovirus vectors and insect cell culture procedures. In Texas Agricultural Experiment Station Bulletin No 1555. 1987.

29. Martens JWM, Honee G, Zuidema D, Lent JWMV, Visser B, Vlak JM: Insecticidal activity of a bacterial crystal protein expressed by a recombinant baculovirus in insect cells. Appl Environ Microbiol 1990, 56:2764-2770.

30. Chang JH, Choi JY, Jin BR, Roh JY, Olszewski JA, Seo SJ, O'Reilly DR, Je YH: An improved baculovirus insecticide producing occlusion bodies that contain Bacillus thuringiensis insect toxin. J Invertebr Pathol 2003, 84:30-37.

31. Hofte $H$, Whiteley HR: Insecticides crystal proteins of Bacillus thuringiensis. Microbial Rev 1989, 53:242-252.

32. Kim JS, Choi JY, Chang JH, Shim HJ, Roh JY, Jin BR, Je YH: Characterization of an improved recombinant baculovirus producing polyhedral that contain Bacillus thuringiensis Cry1Ac crystal protein. J Microbiol Biotechnol 2005, 15:710-715.

33. Ribeiro BM, Crook NE: Expression of full-length and truncated forms of crystal protein genes from Bacillus thuringiensis subsp. kurstaki in a baculovirus and pathogenicity of recombinant viruses. J Invertebr Pathol 1993, 62:121-130.

34. Rajendra W, Hackett KJ, Buckley E: Functional expression of lepidopteranselective neurotoxin in baculovirus: Potential for effective pest managenent. Biochim Biophys Acta 2006, 1760:158-163.

35. Shim H, Choi J, Li M, Wang Y, Roh J, Woo SJ, Je BY: A novel recombinant baculovirus expressing insect neurotoxin and producing occlusion bodies that contain Bacillus thuringiensis Cry toxin. J Invertebr Pathol 2009, 12:217-220. 
36. Hofmann $\mathrm{C}$, Vanderbruggen $\mathrm{H}$, Hüfte $\mathrm{H}$, Van Rie J, Jansen $\mathrm{S}$, Van Mellaert $\mathrm{H}$ : Specificity of Bacillus thuringiensis delta-endotoxins is correlated with the presence of high-affinity binding sites in the brush border membrane of target insect mid-gut. Proc Natl Acad Sci U S A 1988, 85:7844-7848.

37. Seo JH, Li L, Yeo JS, Cha HJ: Baculoviral polyhedrin as a novel fusion partner for formation of inclusion body in Escherichia coli. Biotechnol Bioeng 2003, 84:467-473.

38. Knowles BH, Ellar DJ: Colloid-osmotic lysis is a general feature of the mechanism of action of Bacillus thuringiensis delta-endotoxins with different insect specificity. Biochimica et biophysica acta 1987, 924:509-518.

39. Slatin SL, Abrams CK, English L: Delta-endotoxins form cation-selective channels in planar lipid bilayers, Biochemi and Biophys. Res Commun 1990, 169:765-772.

40. Schwartz JL, Garneau L, Masson L, Brousseau R: Early response of cultured lepidopteran cells to exposure to $\delta$-endotoxin from Bacillus thuringiensis: involvement of calcium and anionic channels. Biochemica et biophysica acta 1991, 1065:250-260.

41. Choi JY, Jung M-P, Park H-H, Tao XY, Byung R, Je YH: Insecticidal activity of recombinant baculovirus co-expressing Bacillus thuringiensis crystal protein and Kunitz-type toxin isolated from the venom of bumblebee Bombus ignites. J Asia Pac Entomol 2013, 16:75-80.

42. McCarthy WJ, Aronson JN, Labenberg J: A 63 kDa toxic polypeptide from Bacillus thuringiensis subsp. kurstaki (HD-263): Effects on several lepidopteran cell line. In Vitro 1988, 24:59-64.

43. Lilley M, Ruffell RN, Somerville HJ: Purification of the insecticidal toxin in crystals of Bacillus thuringiensis. J Gen Microbiol 1980, 118:1-11.

44. van Oers MM, Just M: Vlak Baculovirus. Curr Drug Targets 2007, 8:000-000.

doi:10.1186/1480-9222-16-7

Cite this article as: El-Menofy et al:: A novel recombinant baculovirus overexpressing a Bacillus thuringiensis Cry1 Ab toxin enhances insecticidal activity. Biological Procedures Online 2014 16:7.

\section{Submit your next manuscript to BioMed Central and take full advantage of:}

- Convenient online submission

- Thorough peer review

- No space constraints or color figure charges

- Immediate publication on acceptance

- Inclusion in PubMed, CAS, Scopus and Google Scholar

- Research which is freely available for redistribution 